\title{
Spirit and Flesh: An Interpretation of 1 Corinthians 5:5
}

\author{
Daniel K. Bediako \\ Valley View University, Accra, Ghana
}

\begin{abstract}
1 Corinthians 5:5 presents both exegetical and theo ${ }^{1}$ logical difficulties that relate to the spirit-body dichotomy. After establishing the historical-literary context and analyzing the relevant lexical items of the text, the study submits that Paul's verdict in 1 Corinthians 5:5 is figurative. The Apostle instructs the church to figuratively hand over the incestuous man to Satan (i.e., expel him from fellowship), so that in light of the accompanying disgrace and grief the man would come back to his senses, turn away from his sin, and be accepted back into fellowship. The contrast between "flesh" and "spirit" indicates that either of these terms refers to the person as a whole. It appears that generally Paul uses the "body-soul-spirit" terminology to refer to the totality of the person, but uses "body/flesh-spirit” terminology either as an abbreviation of "body-soul-spirit" or as another form of expressing the old creature/new creature dialectic of Christians.
\end{abstract}

Keywords: spirit, flesh ,Corinthians

\section{Introduction}

In 1 Corinthians 5:5 Paul primarily addresses an incestuous problem in the Corinthian church. The apostle considers the issue critical to the well-being of the church, the sacred temple of God. Unfortunately, however, the Corinthian church seems conceited about this horrendous sin and Paul deprecates this attitude, stating that the church should rather be filled with grief and put the incestuous man out of their fellowship . Further, since the church remains impervious, Paul himself pronounces judgment on the offender and asks the church to carry it out: they should "hand over such one to Satan, unto destruction of the flesh, in order that the spirit might be saved on the day of the Lord” . This harsh, but well-intentioned, verdict of Paul has been a center for scholarly and theological reflection, particularly in the areas of soteriology and church discipline.

1 Corinthians 5:5 has received a legion of scholarly interpretations. Paul's verdict has been understood by some scholars to denote temporary discipline, while others argue that Paul suggests a permanent expulsion of the incestuous man, a punishment which will lead to his death. If the phrase "destruction of the flesh" is taken literally, it may imply physical illness, or physical suffering inflicted by Satan. This has resulted in a "curse/death" interpretation based on analogy from Greek magical papyri and/or Jewish writings. By the phrase "hand over", Paul may have meant a delivery of the man to Roman magistrates, a secret execution, a self-atoning physical death, or a delivery to purgatory. Although some understand "flesh" in a physical sense, namely the body, others understand "flesh" and "spirit" metaphorically, each denoting the whole person rather than a dichotomy of the person. Accordingly, Paul may be referring to the expulsion of the incestuous man

Daniel K. Bediako, PhD ,Valley View University, Ghana.

Correspondence concerning this article should be addressed to P. O. Box AF 595, Adentan, Accra, Ghana. Email: bediako76@yahoo.com. 
leading to the "destruction" of his sinful nature, not his physical body. Still, others see in this expulsion both the mortification of the flesh (fleshly lust) and physical suffering (destruction of the flesh/body). Some scholars, however, have posited an allegorical interpretation: in 1 Cor 5:5 "flesh" and "spirit" do not refer to the incestuous man but to the spiritual life of the church at Corinth, be it the church's orientation to God (i.e., “spirit”) or her orientation away from God (i.e., "flesh”).

The brief overview of the literature indicates that there is no scholarly consensus regarding the meaning of Paul's verdict. While the polarity of interpretations of this verdict necessitates an exhaustive study, 1 Cor 5:3-5 also promises a fertile ground for the mind-body problem. In verdict. 3, Paul contrasts soma "body" with pneuma "spirit": "For I, on my part, though absent in body but present in spirit, have already judged him who has so committed this, as though I were present". In verdict. 5, the Apostle contrasts the destruction of sarx "flesh" with the salvation of pneuma "spirit". How does Paul intend his audience to understand the words "body", "flesh”, and "spirit”? Does the body/spirit or flesh/spirit dialectic in this passage suggest a dichotomy of the human being? What implications have 1 Cor 5:3-5 for the mind-body controversy? These are significant questions that need to be answered, a task which this paper embarks upon. The study is organized as follows: (1) historical-literary context; (2) lexical analysis of relevant phrases; and (3) implications for the mind-body discussion.

\section{The Context}

The ancient city of Corinth is notorious for its sexual impropriety. With this background, one easily understands why sexual immorality of such magnitude could find its way into the church. Paul states that "someone has the wife of his father", an extraordinary case of immorality that is uncommon even among the Gentiles.

The exhortations of Paul in 1 Cor 5:1-13 seem to be based on 3:16-17, where he asserts that the church at Corinth is the temple of God and that those who destroy it will be destroyed by God. With reference to the incestuous relationship, Paul directs the church to put the man out of their fellowship. Verdict. 3-5 state how and why the church should carry out the judgment and verdict. 6-8 give the theological basis for the intended action. In vv. 9-13 Paul excoriates the church's relaxed attitude and seems to suggest that the church should have taken the appropriate action based on his former letter. This context provides the parameters for understanding the verdict in v. 5. By keeping close to this context, most of the scholarly opinions given above will be discarded.

\section{Analysis of 1 Corinthians 5:5}

This section offers lexical-semantic analyses of the following words/phrases within the general context of the Pauline corpus: paradounai "to hand over", eis olethron tēs sarkos "unto destruction of the flesh", and hina to pneuma sōthe "so that the spirit might be saved".

Paul directs that when the church assembles in the name of the Lord with the presence of Paul's spirit, they should paradounai "hand over" the incestuous man to Satan. In the LXX, the root paradidomi is used to refer to God handing over Job to Satan for physical affliction. The word is also used in the sense of God's rejection or abandonment of his people as a form of judgment. In the Gospels, paradidōmi is used in reference to the betrayal of Jesus by Judas . Jesus is also handed over to Pilate, who in turn hands over Jesus back to the people. The word also denotes God's judgment on sinners. It is clear from this that paradidomi may either be literal (physically 
handing someone over for punishment) or figurative (judgmentally rejecting or abandoning someone).

In the context of 1 Cor 5:5, a figurative understanding of paradidōmi seems to be a better option. Paul uses several metaphors in this chapter. Examples include the references to the "old yeast", "Christ our Passover lamb”, and "the feast”. Verdict. 5 may thus be understood. Moreover, in several contexts paradidomi simply implies rejection/abandonment or surrender. In the parallel text of 1 Tim 1:20, the word implies abandonment. Here, Paul says that some believers (Hymenaeus and Alexander) have shipwrecked their faith and that he has handed them over to Satan to be taught not to blaspheme.

Thus understood, paradounai in 1 Cor 5:5 does not refer to a magical spell or curse, nor does it refer to court summons, secret execution, or a self-atoning death. We may take v. 2 as the basic verdict of Paul, and that the rest of the chapter serves to reinforce this verdict. Note also that v. 13 forms an inclusion with $\mathrm{v}$. 2 . This is to say that what vv. 2 and 13 state literally, vv. 5 and 7 state figuratively. In any case, the incestuous man is to be expelled from fellowship. Christ rules within the church and Satan rules outside the church. If the sinner is expelled from church fellowship, he automatically finds himself in the sphere of Satan's operation. Therefore, Paul does not suggest any direct activity of Satan with the incestuous believer.

The phrase eis olethron tēs sarkos literally means "unto destruction of the flesh". The word olethros (olethron is masculine singular accusative of olethros) generally denotes physical destruction. The noun olethros or the verb olethreuo in the LXX may denote destruction or judgment. In the NT olethros has the more general sense of eschatological or spiritual destruction. While olethros may have physical meaning, the figurative tenor of 1 Cor 5:5-7 seems to suggest that, like paradounai, olethron should be taken figuratively. This should also advise against interpreting the text in a strict literal sense. A careful look at the Greek sentence in v. $5 \mathrm{~b}$ seems to indicate that eis olethron tēs sarkos stands in apposition to paradounai tō satana. Both paradounai tō satana and eis olethron tēs sarkos have judgmental connotations and their juxtaposition here suggests that both phrases have the same reference. If so, this means that "hand over such one to Satan" equates or (at least) is explained by "unto destruction of the flesh". Since the hina clause ("in order that the spirit might be saved on the day of the Lord") has the incestuous man in view and syntactically relates to the main clause ("hand over such one to Satan"), hina expresses the intended result of the action in the main clause. In other words, the intended result of paradounai here is the salvation of the incestuous man's spirit.

Having taken olethros in a metaphorical sense, the meaning of sarx (sarkos is the genitive of sarx) needs to be determined. According to A. Sand, sarx is used in three ways: (1) the bodily substance; (2) earthly and natural (merely worldly) existence; and (3) human beings subject to the power of $\sin$. The context of 1 Cor 5 seems to suggest that sarx understood to mean sinful human nature. Sarx refers to the incestuous man, not the worldly inclination of the church. That this is what Paul means is clear even from a cursory reading of verdict. 3-5:

Even though I am not physically present, I am with you in spirit. And I have already passed judgment on the one who did this, just as if I were present. When you are assembled in the name of our Lord Jesus and I am with you in spirit, and the power of our Lord Jesus is present, hand this man over to Satan, so that the sinful nature may be destroyed and his spirit saved on the day of the Lord (NIV). To the church in Corinth (Paul writes)

This understanding of sarx complies with the figurative sense of olethros. The incestuous man is to be expelled from the church, an action which may possibly lead to the destruction of his sinful nature. Accordingly, rather than physical destruction or death, olethros implies the renouncement of the incestuous man's sinful 
nature, namely, turning away from his present fleshly way of life marked by this gross immorality. While olethros is, admittedly, a strong word for destruction, Pauline references to the subjugation of the flesh elsewhere indicate that its use with reference to flesh in 1 Cor 5:5 should not be a surprise or demand literal interpretation. For example, Paul says that those who belong to Christ Jesus have crucified the flesh. He also says that believers must put to death the misdeeds of the body or whatever belongs to the earthly nature . If in such instances Paul does not mean literal crucifixion or death of the flesh, we should not understand olethron sarkos in 1 Cor 5:5 otherwise. The same is true with 1 Tim 1:19-20, the only NT parallel to 1 Cor 5:5. Paul does not consider death as a means of church discipline, since discipline is clearly redemptive .

As argued above, sarx refers to the whole person, namely the sinful nature of the incestuous man. Since in the context of 1 Cor 5 pneuma "spirit" is the antonym of sarx, it follows that pneuma be understood as the man's new nature in Christ which would result from the destruction of his sarx. Thus, pneuma also refers to the person as a whole as oriented towards the will of God. Within vv. 3-5, Paul uses pneuma in two different ways. In v. 3, pneuma contrasts soma: although the Apostle is absent in the body (soma) from the Corinthian church, he is present in the spirit (pneuma). This probably means that while he cannot be physically at Corinth to execute the verdict, he fully undersigns the action . This is where pneuma "spirit" intercepts with nous "mind". In v. 5, however, the contrast is between sarx "flesh" and pneuma "spirit". The soma of v. 3 does not neatly equate the sarx of v. 5, and there is also a change in nuance of pneuma in v. 5. Both sarx and pneuma are figurative in v. 5, each referring to the whole, undivided being. They also correspond to Paul's old nature/new nature antithesis . Rosner's statement is well-noted:

When Paul contrasts flesh and spirit, as here in v. 5, flesh refers almost without exception to the contrast of evil and good tendencies, as in Romans 8:5-17 and Galatians 5:16-24. 'Flesh' refers to the person oriented away from God and 'spirit' to the person oriented towards God.

In Pauline writings salvation may be present or eschatological. The significance of sōthe "might be saved" (aorist subjunctive passive of $s \bar{o} z \bar{o}$ ) in 1 Cor $5: 5$ is often not debated. Nonetheless, the reference to the salvation of the spirit "on the day of the Lord" presents some difficulty. Do we have to construe salvation here in an eschatological sense because sōthe is qualified by "the day of the Lord"? On the other hand, if Paul envisioned the return of the incestuous man after the destruction of the "flesh", would he situate the salvation of the man's "spirit" only at the eschaton? Gordon Fee makes the point that "the day of the Lord" is one of Paul's "ordinary ways of expressing salvation.” Thus understood, Paul may not necessarily have attached temporal significance to the phrase. It is also true that Paul elsewhere envisions the day of the Lord with considerable immediacy. However, nothing in the context of 1 Cor 5 argues against understanding the day of the Lord in an eschatological sense. In the parallel text of 1 Tim 1:19-20, Paul seems to expect the repentance of nae and Alexander when he says that he has given them over to Satan to be taught not to blaspheme. Similarly, in 1 Cor 5:5 the repentance of the man seems to be assumed by Paul. On this basis, he proleptically (bypassing the intermediate) announces the eschatological salvation of the incestuous man once he repents. In any case, Paul's verdict in 1 Cor 5:5 as elsewhere seems redemptive.

Although the interpretation of 1 Cor 5:5 given in this article is not entirely new, it has added weight to the "expulsion view". Some scholars advocate this interpretation, yet, based on analogy with Job's suffering and Paul's thorn in the flesh, they seem to (or at least doubt whether such interpretation does not) envision the physical involvement of Satan in destroying the "flesh" of the incestuous man. This brief study has forcefully 
argued a figurative understanding of Paul's injunction in 1 Cor 5:5. Accordingly, Satan plays no role in this non-literal destruction of the flesh. If, as stated above, "unto destruction of the flesh" stands in apposition to "hand over such one to Satan", then the difficulty disappears. By figuratively handing over the incestuous man to Satan (i.e., expelling him from the church), it is hoped, in view of the accompanying disgrace and grief, that the man would come back to his senses, repent of his sin, turn away from it, and be accepted back into fellowship.

\section{Implications}

1 Corinthians 5 has implications both for understanding the spirit-flesh dialectic and for church discipline. Although Paul uses the terms "body/flesh", "spirit", and "soul” or simply "body” and "spirit” with reference to the individual, he does not seem to denote that each of these terms refers to an entity that can exist on its own . Even if the use of these terms raises some ambiguity elsewhere, in 1 Cor 5:5 the contrast between "flesh" and "spirit" indicates that either of these terms refers to the person as a whole. Second, "body" in verdict. 3 denotes physical presence while "spirit” denotes mental assent. Here, "body" and "spirit” are not distinct entities. Third, Sand has rightly noted that Paul, as well as the NT, has no dichotomous/dualistic view of the human being. It appears that Paul uses the "body-soul-spirit" terminology to refer to the totality of the person, but uses "body/flesh-spirit" terminology either as an abbreviation of "body-soul-spirit" or as another form of expressing the old creature/new creature dialectic of Christians . 1 Corinthians 5 also suggests that church discipline is relevant even for the twenty-first century church. Discipline is primarily remedial. It results not only in the redemption of an erring Christian but also in purifying the community of believers as a whole.

\section{References}

Barrett, C. K. (1968). A commentary on the first epistle to the Corinthians. San Francisco: Harper \& Row.

Blomberg, C. L. (1994). 1 Corinthians. NIV Application Commentary. Grand Rapids: Zondervan.

Brauch, M. T. (1989). Hard sayings of Paul. Downers Grove, IL: Inter Varsity.

Bruce, F. F. (1971). 1 and 2 Corinthians. London: Oliphants.

Bultmann, R. (1951-1955). Theology of the New Testament (Vols. 1-5). New York: Scribner's.

Caird, G. B. (1969). New Testament Theology. Oxford: Clarendon.

Campbell, B. (1993). Flesh and spirit in 1 Cor 5:5: An exercise in rhetorical criticism of the NT. Journal of the Evangelical Theological Society, 36 (1), 331-342.

Colins, Adela Yarbro. (1980). The function of ‘Excommunication' in Paul. Harvard Theological Review, 73(1), 254-63.

Conzelmann, Hans. (1975). 1 Corinthians: A commentary on the first epistle to Corinthians. Hermeneia. Philadelphia: Fortress.

Craig, C. T. \& Short, J. (1953). The first epistle to the Corinthians. Interpreter's Bible (Vol. 10). New York: Abingdon.

Deissmann, A. (1911). Light from the ancient East. New York: Hodder \& Stoughton.

Derrett, J. D. M. (1979). “Handing over to Satan”: An explanation of 1 Cor 5:1-7. Revue Internationale des

Donfried, K. P. (1976). Justification and last judgment in Paul. Interpretation, 30 (1), 140-152.

Edwards, T. C. (1979). 1 Corinthians. Minneapolis, MN: Klock \& Klock.

Fee, Gordon D. (1987). The first epistle to the Corinthians. The new international commentary on the New Testament. Grand Rapids: Eerdmans.

Gilmour, S. M. (1963-1964). Pastoral care in the New Testament church. New Testament Studies, 10 (3), 393-98.

Godet, F. L. (1997). Commentary on first Corinthians. Grand Rapids: Kregel.

Grosheide, F. W. (1963). Commentary on the first epistle to the Corinthians. New international commentary on the New Testament. Grand Rapids: Eerdmans.

Guthrie, D. (1981). New Testament theology. Downers Grove, IL: Inter Varsity.

Hafemann, S. J. (2000). 2 Corinthians. The NIV application commentary. Grand Rapids: Zondervan.

Harris, G. (1991). The beginnings of church discipline: 1 Corinthians 5. New Testament Studies, 37(1), 1-21. 
Hurd Jr., J. C. (1965). The origin of 1 Corinthians. New York: Seabury.

Klausner, J. (1946). From Jesus to Paul. London: Allen and Unwin.

Lenski, R. C. H. (1961). The interpretation of St. Paul's first and second epistles to the Corinthians. Minneapolis, MN: Augsburg.

MacArthur, S. D. (1978). "Spirit” in Pauline usage: 1 Corinthians 5:5. Studia Biblica, 1, 249-56.

Mare, W. Harold. (1976). 1 Corinthians. The expositor's Bible commentary(Vol. 10). Grand Rapids: Zondervan.

Marsh, P. W. (1969). 1 Corinthians. A New Testament Commentary. Zondervan.

Morris, L. (1958). The first epistle to the Corinthians: An introduction and commentary. Grand Rapids: Eerdmans.

Murphy O’Connor, J. (1990). The first letter to the Corinthians, new Jerome biblical commentary (ed.). Raymond E. Brown. Englewood Cliffs, NJ: Prentice Hall.

Olshausen, H. (1984). A commentary on Paul's first and second epistles to the Corinthians. Minneapolis, MN: Klock \& Klock.

Orr, W. F., \& Walther, J. A. (1976). 1 Corinthians. AB. Garden City: Doubleday.

Richards, W. L. (1997). 1 Corinthians, the abundant life Bible amplifier (ed.). George R. Knight. Nampa, ID: Pacific Press.

Ridderbos, H. (1975). Paul: An outline of his theology. Grand Rapids: Eerdmans.

Robertson, A. T. (1931). Word pictures in the New Testament (Vol. 4). Nashville, TN: Broadman.

Robertson, A., \& Plummer, A. (1916). A critical and exegetical commentary on the first epistle of St. Paul to the Corinthians. International critical commentary. New York: Schribner's.

Rosner, B. S. (1999). “Drive out the wicked person”: A biblical theology of exclusion. Evangelical Quarterly, 71 (1), 25-36.

Rosner, B. S. (1991). Temple and holiness in 1 Cor 5.Tyndale Bulletin, 42 (1), 137-45.

Ruef, J. (1977). Paul's first letter to Corinth. Philadelphia: Westminster.

Schneider, J. (Ed.).(1971). “Olethros.” Theological Dictionary of the New Testament(Vol.5). (Gerhard Kittel \& Geoffrey W. Bromiley, Trans.). Grand Rapids: Eerdmans.

Schweizer, E. (1971). "Sarx, sarkikos, sarkinos.” Theological dictionary of the New Testament. (Gerhard Kittel \& Geoffrey W. Bromiley, Trans.). Grand Rapids: Eerdmans.

Shillington, V. George. (1998). Atonement texture in 1 Corinthians 5:5. Journal for the Study of the New Testament, 71 (1), 29-50.

South, James T. (1993). A critique of the “Curse/Death” interpretation of 1 Corinthians 5:1-8. New Testament Studies, 39 (1), 539-561.

Stanley, A. P. (1981). The epistles of St. Paul to the Corinthians (2nd ed.). Minneapolis, MN: Klock \& Klock.

Stauffer, E. (1955). New testament theology. New York: Macmillan.

Thiselton, A. C. (1973). The meaning of $S A R X$ in 1 Corinthians 5:5: A fresh approach in the light of logical and semantic factors. Scottish Journal of Theology, 26 (1), 204-28.

Thrall, M. E. (1965). The first and second letters of Paul to the Corinthians. Cambridge: Cambridge University Press.

Von Campenhausen, H. (1969). Ecclesiastical authority and scriptural power in the church of the first three centuries. Stanford: Stanford University Press.

Walter, E. (1981). The epistle to the Corinthians. New York: Crossroad.

Watson, N. (1992). The first epistle to the Corinthians. London: Epworth. 